\title{
Beyond Degree Programs: How a Major University Immersed Itself in the Educational Landscape of New York City
}

\section{Anita Vazquez Batisti, Michael E. Pizzingrillo}

Fordham University Graduate School of Education Center for Educational Partnerships, USA.

\begin{abstract}
In 2006 the Center for Educational Partnerships was established as the “outreach arm” of Fordham University's Graduate School of Education. In so doing, Fordham reimagined the role of higher education to go beyond degree granting programs, faculty expertise and research opportunities. In this paper, we describe how what began in 2006 as a vision to strengthen the presence of the Graduate School of Education in New York City public schools has grown into a thriving Center that touches the lives of more than 500,000 students in grades Pre-K to 12, thousands of teachers, and hundreds of administrators and parents throughout New York City.

We outline how each phase of Fordham's involvement and work developed during New York City's major educational reform agenda, resulting from the New York State Legislature's granting the City's mayor control of New York City's 1,500 public schools in 2002.
\end{abstract}

Keywords: higher education; education reform; N.Y.C. Public Schools; partnerships. 


\section{Introduction}

In 2006, the Center for Educational Partnerships (CEP) was established as the "outreach arm" of Fordham University's Graduate School of Education (GSE). In so doing, Fordham reimagined the role of higher education to go beyond degree granting programs and certification tracks. By establishing technical assistance centers, and becoming a Partnership Support Organization, and subsequently a Community School partner, the CEP immersed itself in new models and initiatives to service public and non-public schools throughout NYC.

Both the New York City Department of Education (NYCDOE) and the New York State Education Department (NYSED) have always initiated programs and services for which eligible organizations-profit and non-profit, institutions of higher education (IHE), Community Based Organizations (CBO) — can submit proposals for funding. Most IHEs respond to expand the programs and partnerships they normally provide; namely, degree programs, faculty expertise, research opportunities, student teachers, and leadership interns.

In this paper, we describe the establishment and mission of the CEP which is enabling Fordham University's Graduate School of Education to advance beyond traditional programs and services. Section 2 describes the establishment of the CEP. The remaining sections of this paper are as follows: section 3 covers the early stages of Fordham's transition; sections 4 and 5 describe how Fordham through the CEP immersed itself in the educational landscape of New York City. Section 6 concludes the paper with a summary and discussion of further work in the future.

\section{The Center for Educational Partnerships}

What began as a vision in 2006 to strengthen the presence of the GSE in New York City public schools has grown into a thriving Center that touches the lives of more than 500,000 students in grades Pre-K to 12 (ages 3-18), thousands of teachers, hundreds of administrators and parents throughout New York City and the greater metropolitan area: with programs servicing both public and non-public schools.

The Center is not a think tank. At the heart of its mission since it was established in January 2006 by James J. Hennessy, Ph.D., now Dean Emeritus of the Fordham Graduate School of Education and Anita Vazquez Batisti, Ph.D., Associate Dean for Partnerships, is action and collaboration. The Center is research based and outcome oriented; with the goal of bringing critical resources and expertise to bear on services to those student populations most at-risk of academic failure.

A hallmark of the Center for Educational Partnerships is its community of professionals. Not only does our intellectual community involve faculty, but also practitioners and graduate students. We bring to bear a rich array of resources to each project, tailoring our approach to 
the specific circumstances, unique challenges, and opportunities that exist. Current GSE Dean, Virginia Roach, Ed.D., states "Jesuit education is steeped in the notion of cura personalis, or care for the entire person as an individual endowed with particular gifts and insights." So too is our work.

\section{Phase One-Transition}

The New York City public school system is the largest in the United States, consisting of 1.1 million Pre-K to 12 grade students and 1,800 schools with a budget of over $\$ 34$ billion. The need for instructional support in the form of professional development for current teachers is and has always been of importance.

\subsection{Professional Development}

"Not every teacher has the opportunity to go to Fordham, but all teachers can have Fordham come to them." In 2006, the Center began working on a daily basis in numerous schools throughout the city, providing on-site in-classroom coaching for teachers in support of mathematics and literacy instruction. Fordham coaches model, demonstrate, and team teach using the reflective practitioner approach. Fordham coaches are highly experienced active practitioners guided by research based best practices as part of our faculty input.

\subsection{Technical Assistance}

Also in 2006, Fordham's Graduate School of Education through the Center for Educational Partnerships was awarded a major contract from the New York State Education Department (NYSED) to establish a Bilingual Education Technical Assistance Center (BETAC) to serve all 326 New York City Schools in the Bronx. The success of this initiative paved the way in 2011 for a subsequent award from NYSED to establish the NYC Regional Bilingual Education Resource Network (RBERN), serving all of New York City. As the linear successor to Fordham's five-year BETAC, the new RBERN provides technical assistance and professional development to NYCDOE schools, which have large concentrations of students and parents who are English Language Learners (ELLs) with a focus on low achieving schools. Fordham's RBERN works in cooperation with NYCDOE's Office of Multilingual Learners providing services for the 149,000 English Language Learners throughout New York City's public schools.

During this period, Fordham also established a Bilingual School Psychology Support Center. Fordham teamed with the New York City Department of Education to recruit, train, and retain Bilingual School Psychologists city-wide. The Bilingual School Psychology Support Center was funded by the New York State Department of Education and served as an information clearinghouse for both aspiring school psychologists and those currently working in NYC schools. A hallmark of this project was its intercollegiate collaboration. 


\section{Phase Two-Further Transition and Involvement}

\subsection{Background}

In May 2002, New York State under Assembly bill A11627 and Senate bill S07456B, granted Mayoral control to Mayor Michael Bloomberg. "After 32 years of governance by a sevenmember appointed Board of Education in conjunction with 32 locally elected boards, the system came under the aegis of the city's mayor, who established the DOE in 2000 and had the power to appoint the chancellor and other key personnel." (Childress \& Clayton, 2008). In October 2002, about nine months after Bloomberg took office, he and schools Chancellor Joel Klein unveiled “Children First: A New Agenda for Public Education” (Hill, 2013).

The Center for Educational Partnerships was established during the Mayor's second term; however the opportunity to be part of the further re-organization of the NYCDOE and expansion of the School Chancellor's reform agenda which sought and invited private entities to become a Partnership Support Organization (PSO), happened in 2007.

NYCDOE issued a Request for Proposals in 2007, stating: "Partnership School Support refers to the provision of a set of services to support principals, school leadership teams and school staff in improving student performance and achieving school level accountability goals, as described in Section 3 of this RFP. The Partnership School Support model described herein is designed to promote student achievement by providing the NYCDOE and school leaders with access to alternative models for support in coordination and collaboration with a Children First Network. It will also allow the NYCDOE to infuse greater accountability into relationships with external organizations that provide support to schools with the expectation that this will, in turn, result in improved support to schools and improved student performance." NYCDOE defines partners as "individuals and organizations who enter collaborative relationships with schools and school districts" (Scott and DiMartino, 2009).

\subsection{Next Steps in Transition}

Fordham through the CEP was ready for the next step in its transition. Through a competitive proposal application process, Fordham was one of seven organizations chosen as a PSO and the only private university. In the first year we began with a network of 10 (Pre-K to 12) grade schools; the following year 16 schools; then 24 schools; then to 35 schools serving 19,000 Pre-K to grade 12 students throughout New York City.

The mission of the Fordham PSO collaboration with New York City schools was to help teachers and administrators drive academic achievement through a process of reflection, selfanalysis, and the integration of perspectives gained from research into school-wide and classroom practice. The goal was to move each school toward the tipping point at which its culture became one of accountability and accomplishment. 
The Fordham team focused on keeping their network of schools prepared to meet the challenge of an evolving system by providing operational, instructional, and leadership supports that maximized academic achievement, built teacher capacity, and created environments that best served all constituents.

\subsection{Results Obtained}

As a result of the PSO, Fordham's partner schools demonstrated the following:

- Growth and sustainability (growth from 10 schools in 2007 to 35 schools in 2012)

- Principals' Satisfaction Survey resulted in $100 \%$ satisfaction with Fordham in all categories, well above the city average. Categories included utilizing resources, facilitation of community, best practice sharing among the network principals, crisis management, instruction, operations, and communications.

- Academic Achievement - Fordham accepted partnerships with schools applying differing instructional philosophies and provided tailor-made support to maximize student achievement. The following chart highlights the successes of a cross section of students from vastly different socio-economic districts and widely disparate student populations.

Table 2. Fordham PSO Elementary and Middle Schools Academic Achievement.

\begin{tabular}{|c|c|c|c|c|c|c|}
\hline Joined & $\begin{array}{l}\text { ATS } \\
\text { DBN }\end{array}$ & School Name & $\begin{array}{l}\text { Grades } \\
\text { Served }\end{array}$ & $\begin{array}{l}2010 \text { Prog } \\
\text { Report }\end{array}$ & $\begin{array}{l}2011 \text { Prog } \\
\text { Report }\end{array}$ & $\begin{array}{l}2012 \text { Prog } \\
\text { Report }\end{array}$ \\
\hline 2009 & $05 \mathrm{M} 129$ & PS 129 John H Finley & pK-8 & B & $\mathrm{C}$ & B \\
\hline 2010 & $05 \mathrm{M} 194$ & PS 194 Countee Cullen & pK-5 & $\mathrm{C}$ & $\mathrm{D}$ & B \\
\hline 2009 & 06M004 & PS 004 Duke Ellington & pK-5 & B & B & B \\
\hline 2007 & $06 \mathrm{M} 325$ & PS 325 & K-5 & $\mathrm{C}$ & $\mathrm{C}$ & B \\
\hline 2010 & 07X005 & PS 005 Port Morris & K-5 & $\mathrm{C}$ & B & B \\
\hline 2009 & 11X096 & PS 096 Richard Rodgers & K-5 & B & B & B \\
\hline 2010 & $16 \mathrm{~K} 335$ & PS 335 Grantville T Woods & K-5 & B & A & A \\
\hline 2007 & 25Q209 & PS 209 Clearview Gardens & pK-5 & A & A & A \\
\hline 2007 & 09X117 & Joseph H Wade & $6-8$ & B & $\mathrm{C}$ & B \\
\hline 2010 & $09 X 454$ & Mott Hall S\&T & $6-8$ & - & A & A \\
\hline 2010 & 09X454 & Mott Hall S\&T & $6-8$ & - & A & A \\
\hline
\end{tabular}

Source: CEP Internal Documents (2016). 
Table 2. Fordham PSO High Schools Academic Achievement.

\begin{tabular}{ccccccc}
\hline Joined & $\begin{array}{c}\text { ATS } \\
\text { DBN }\end{array}$ & School Name & $\begin{array}{c}\text { Grades } \\
\text { Served }\end{array}$ & $\begin{array}{c}\mathbf{2 0 1 0} \\
\text { Report }\end{array}$ & $\begin{array}{c}\mathbf{2 0 1 1} \\
\text { Report }\end{array}$ & $\begin{array}{c}\mathbf{2 0 1 2} \\
\text { Report }\end{array}$ \\
\hline 2009 & 10 X342 & ISLA HS & HS & B & C & B \\
2009 & 10 X549 & Discovery HS & HS & A & A & A \\
2007 & 11 X513 & New World HS & HS & A & B & A \\
\hline
\end{tabular}

Source: CEP Internal Documents (2016).

\section{High School Graduation Data}

Four out of six of our High Schools exceeded the citywide four year graduation rate of $61 \%$ as of June 2011, as posted on the NYCDOE website. Additionally, five out of six schools increased graduation rates in the 2012 school year.

\section{Phase Three - Full Immersion}

\subsection{Background}

In 2014, newly elected mayor Bill de Blasio restored the power of the 32 District Superintendents and eliminated the NYCDOE networks and the private sector networks PSOs which included Fordham's network. De Blasio then unveiled a Strategic Plan implementing the Community Schools Model to address the needs of NYC's at risk schools.

\subsection{Programs and Initiatives}

Partnerships with Community Schools. In 2015, "Mayor de Blasio announced that the Community Schools model would be central to the City's ambitious efforts to support 94 Renewal Schools (schools identified as Priority or Focus schools by the State, demonstrated low academic achievement for each of the three prior years)" (Retrieved from https://sites.google.com/mynycschool.org/newyorkcitycommunityschools/home/about). As a result of Mayor de Blasio's paradigm shift in school improvement, the CEP refocused its efforts to partner with New York City public schools. Identifying two schools in the Bronx, P.S. 85 and M.S. 331, the CEP shifted its focus to delve deeper into the work of these struggling school communities. The efforts are driven by CEP staffing (community school directors, extended learning time coordinators, mental health providers, and educational specialists), all meeting the needs of the over 1,500 students in the two schools.

Community Schools Technical Assistance Center (CSTAC). In 2017, in response to the growing community schools movement, the NYSED announced its plan to establish regional 
Technical Assistance Centers to support schools and school districts. The responsibilities of the TACs include statewide dissemination of information on effective and promising practices in the establishment and ongoing management of Community School strategies through professional development and technical assistance activities (Retrieved from http://www.nysed.gov/budget-coordination/community-school-regional-technical-assistance-centers). The CEP viewed this as an opportunity to expand its reach of support and capacity building to all existing and aspiring community schools within New York City. When awarded in 2018, Fordham established the CSTAC and immediately provided professional development targeted at the full-service community school model, conducted site visits to schools throughout NYC, and expanded its services to include building communities of practice, providing resource referrals for social and other ancillary services, and conducting webinars for the first time as a means of virtual training.

\section{Professional Development Resource Center (PDRC) for Religious and Independent}

Schools. In 2019, as a result of significant advocacy efforts by the religious and independent schools in New York State, the NYSED posted a request for proposals for organizations to serve the schools with professional development. The CEP, with a track record of successful professional development in religious schools in New York City, responded to the State with a comprehensive and culturally-sensitive plan for services. The CEP was successful in its application and was awarded the PDRC for all 800+ Independent and Religious Schools throughout New York City. The PDRC is in the midst of start-up activities including the creation of a needs assessment and preliminary planning for a variety of professional development work including large-scale institutes, webinars, online communities of practice, and in-person workshops.

\section{Conclusion}

As noted by Wilson (2012), a vision to contribute in meaningful ways to improve New York City's public schools, coupled with faculty and graduate students' desire to work with schools in underserved neighborhoods fueled Fordham's outreach to New York City schools. The establishment of Fordham's Center for Educational Partnerships at the Graduate School of Education propelled Fordham's immersion in the educational landscape of New York City public schools and in so doing, transformed the university's relationship with the system.

"The projects at the Center for Educational Partnerships allow us to deepen our involvement with schools because the work isn't at the theoretical level. We are in those buildings working with teachers and administrators to help improve student learning." James J. Hennessy, Ph.D., Dean Emeritus, Graduate School of Education (2008). Immersing itself in the educational landscape of New York City was in keeping with the University's mission. "This is what Fordham is about: teaching teachers and helping them set hearts on fire in their 
students, so that a greater city and a greater nation can be built.” Joseph M. McShane, S.J. President of Fordham University (2007).

\subsection{Summary}

The programs and initiatives we have implemented in numerous schools throughout NYC have enabled students to reach higher levels of academic achievement, teachers and administrators to grow professionally, parents to become more knowledgeable and involved, and greater resources and services to be part of each school community. This assertion is evidenced by annual State criterion-referenced assessments in English Language Arts and Math, bilingual students' English proficiency, annual program evaluations and satisfaction surveys received from teachers, administrators, and parents. The work we are doing benefits our faculty and graduate students as well; namely in the areas of research, and doctoral work, increased field experiences, as well as tutoring and mentoring opportunities. "It's such a positive development for universities to become more interested in the needs of the schools and it's making the university a more well-rounded place as well." Dennis Walcott, Chancellor NYCDOE, "Inside Fordham" - Winter 2012

\subsection{Future Work}

The Center for Educational Partnerships at GSE, with support from GSE Dean Virginia Roach, has begun, and will continue, working with other Fordham University graduate schools to expand services. This includes enabling Fordham's Schools of Arts and Sciences, Social Service, Law, and Business to work directly in schools as part of joint collaborations with the CEP. We have also begun working with national and international organizations like Ashoka, who in 2015 invited CEP to be part of its Inaugural Education Track.

\section{References}

Childress S. \& Clayton T. (2008). Focusing on results at the New York City department of education. Public Education Leadership Project at Harvard University, 2-3.

Hill, P. (2013) Bloomberg's education plan is working: don't ditch it. The Atlantic. https://www.theatlantic.com/education/archive/2013/10/bloombergs-education-plan-isworking-dont-ditch-it/280704/

Office of the Mayor (2014) New York City Community Schools Strategic Plan. NYC.gov.

Scott, J. \& DiMartino C. (2009) Public education under new management: a typology of educational privatization applied to New York City's restructuring. Peabody Journal of Education. DOI: 10.1080/01619560902973647

State of New York Legislation (2002). Assembly 11627 and Senate 07456. Albany, NY.

Wilson, D. (2012) Teach the teachers. Fordham Magazine, Winter 2012, 16-20 